Ryszard Machnikowski

\title{
3. TERRORISM AS A THREAT TO PUBLIC ORDER
}

\subsection{Terrorism: definition and history}

\subsubsection{Problems with the definition of terrorism}

Terrorist activity is not difficult to define, yet the definitions of terrorism are frequently considered controversial, and this sometimes leads to their rejection. One popular type of criticism is neatly expressed in a popular (and deceptive) idiom - 'One man's terrorist is another man's freedom fighter.' This kind of criticism reveals a politically-motivated inability to deal with the consequences of defining terrorism, rather than an intellectual inability to properly grasp it. The major problem with the idea of terrorism seems to be that it is frequently used as a tool to delegitimize the enemy and its actions. Calling a group or a person a terrorist excludes them from normal political discourse. The meaning of the word is not neutral - on the contrary, it is pejorative and it is used to totally morally disqualify a (usually violent) political opponent.

To avoid endless and inconclusive debates we should understand acts of terrorism as a means of political violence, and try to focus our attention on the specific types of violent activity undertaken by the perpetrators of terrorist acts. Consequently, we must attempt not to apply any moral judgment to the concept, and not to wonder whether a terrorists' aims are right or wrong. In all states endangered by it, terrorism is simply considered illegal and criminal in nature.

\subsubsection{The definition of terrorism}

Terrorism, then, is a method of warfare used in violent political conflict, which covers all kinds of activity leading to pre-planned armed attack(s), or credible threat(s) of such attacks on non-combatant targets. The aim of such attacks is to use these acts to achieve political and ideological goals through coercion or intimidation of a public and/or a government.

Regardless of the precise motives of militants resorting to terrorism or justification of their actions i.e. whether they're fighting for freedom or oppression, if their violent attacks deliberately focus on non-combatants and are aimed at harming them physically and psychologically, they should be considered terrorist entities. 
Terrorism is a conscious, organized, clandestine activity that is not limited to carrying out unique terrorist attacks. Such attacks are, per se, crucial elements of the terrorist process. Both individuals and groups involved in terrorist activity must engage in a wide variety of preparatory and organisational tasks in order to carry out an actual attack, or at least credibly threaten a government and society with such an attack, in order to then disseminate their political message and benefit from the political and social reaction to it. Since early anarchist attacks in the late $19^{\text {th }}$ Century, terrorism has often been often described as 'propaganda by deeds'. Terrorist plotters usually consider various options for their attacks, but are necessarily involved in fundraising, training, acquiring and assembling materials - including for weapons and explosives - planning and even rehearsing attacks. This also includes maintaining their own security, avoiding detection by security forces, and covertly communicating. Terrorists must also engage in an everyday life, even if they are detached from society, so quite a substantial part of their lives is devoted to non-terrorist activities. Instigation, recruitment and preparation are all important elements of the terrorist's process - without them, terrorist activity would be short-lived and unsuccessful - considering the fact that terrorists must deal with very powerful state institutions, including the police, special services and military.

The essence of terrorism is that it is a deliberate attack on so called noncombatants - civilians and unsuspecting police or armed forces and/or their infrastructure. Surprise attacks on unprepared, defenceless (sometimes randomly selected) victims are obviously a pre-planned activity. So-called soft targets are easy to strike and difficult to protect. Moreover, attacks on ordinary members of the public have a crucial psychological effect of mass fear and intimidation. The alleged randomness of such attacks results in a public feeling that anybody could be a victim of terrorists, and this instigates feelings of shock and awe. Terrorism is far less about creating huge material damage (although this does sometimes happen (e.g. the 9/11 attacks)), but more about creating a damaging mass psychological effect. Terrorism is a weapon of psychological manipulation. Its effectiveness is not measured by the number of people it kills and injures, but the number of those affected by it, and 'scared to death. Fear is a major driving force and is used by terrorists to manipulate, influence, or even change the minds of decision makers in order to achieve their goals. These goals are of a political and ideological (including religious) nature, even if they ultimately may seem utopian and unrealizable.

\subsubsection{Terrorism as tactics and terrorism as a strategy}

We should perceive the methods of terrorism as both a set of tactics and a strategy. Tactics is based on attacking defenceless targets (even if actually they are armed, like police or military men and women, but in a situation of a surprising attack outside of the battle field) with the use of various weapons 
- today this includes the weaponization of ordinary, every-day items - such as cars, trucks, airplanes etc. As the state cannot protect everyone everywhere, these attacks are relatively easy to pull off and seem to show the ineffectiveness of a state's countermeasures. It is hoped that this will prove the ultimate inability of the state to perform its first and foremost objective - to provide public security. As a result, people can feel defenceless and abandoned by their government, and this can lead to a loss of trust in state institutions - significant social and political damage.

Terrorism as a strategy aims at provoking over-sized and non-proportional reactions from both society and state institutions, changing their behaviour, policies and politics. In their own minds, this gives the attackers' cause a sense of importance and enables them to spread their message for free, gaining world public opinion, and consequently to recruit new supporters and members.

\subsubsection{Terrorism and other forms of political violence}

Some violent groups tend to limit themselves to terrorist methods, in order to politically influence the government and the public. Others treat it as just one of many forms of violent activity that can be used, amongst assassinations, targeted killings, guerrilla warfare, or even regular war, depending on their means. Hence, some organizations can be called pure terrorist groups (e.g. the Rote Armee Fraction, IRA, ETA, Revolutionary Organization November 17), while others are in fact both guerrilla and terrorist groups (e.g. the Taliban, Islamic State, etc). They can even be considered political parties with their own military wings (e.g. Hezbollah in Lebanon, the Palestinian Al Fatah and Hamas organizations).

Moreover, the states themselves are precisely those organizations which began by using fear and intimidation, incited by attacking so-called noncombatant targets, in order to terrorize their society on a mass scale. This type of action is usually referred to as 'state terror'. In fact, the very notion of terrorism was introduced by the Academie francaise in 1798, derived from the dreadful realities of public terror in post-revolutionary France. This French new revolutionary regime applied mass and extreme violence against its own civilian population, in order to prevail in a civil war. The exact number of victims of state terror is unknown, but it does reach into the hundreds of thousands dead and millions intimidated. State terror is perpetrated by government institutions specifically designed to instil public fear. In fact, any totalitarian and authoritarian political regime could be considered a 'leaders' in the mass killing and intimidation of the public - even today, no terrorist entity, be it Islamic State or Al Qaeda, has been able to kill on a scale comparable to those who have perished in state detention camps, gulags, prisons and unofficial 'black sites'. The most lethal act of specific terrorism so far is the '9/11' attack on the World Trade Centre towers and the Pentagon building, which claimed the lives of 2,977 victims in New York, Washington 
D.C. and Somerset County, Pennsylvania. But even so, Revolutionary France, Nazi Germany, Soviet Russia, communist North Korea and Latin America's authoritarian states have altogether managed to kill millions, and scare entire nations to death. This is not to mitigate the terrorists' actions, but to put them in a historical context. They definitely break the state's monopoly to use violence but so far have been unable to achieve its deadly scale and effectiveness.

\subsubsection{The origins and history of terrorism}

The first wave of terrorism in the modern world came with the emergence of an ideology of anarchism that provided active individuals with the motives to attack civilians in a state of non-belligerence. Some currents of anarchism advocated the use of violence precisely against the state and all oppressive regimes, which gave birth to numerous anarchistic organizations and individuals carrying out attacks in the name of the anarchist revolution worldwide. They attempted to 'decapitate' the system by attacking heads of states (kings, presidents, prime ministers, MPs) but ultimately also did not hesitate to plant bombs in restaurants, cafes and theatres, targeting and killing their fellow citizens. Together with other far left revolutionaries, they are responsible for literally hundreds of attacks in the West, harming thousands of people altogether in the late $19^{\text {th }}$ and early $20^{\text {th }}$ centuries. Only World War I ultimately stopped them, and dwarfed the number of victims by millions. The war proves that state-organized violence is much more effective, if not persistent. Anarchists ultimately ceased their political warfare for a while, but the rise of the powerful Bolshevik, fascist and Nazi social movements, which were more than willing to use political violence on a mass scale to terrorize their political opponents, caused a further twist in terrorism's progress.

Soviet Russia, fascist Italy and Nazi Germany proved to be quite efficient in executing their powers through mass, violent intimidation of their public, and after World War II, other ideological currents emerged that helped establish new terrorist-type organizations. Some were motivated by an ideology of decolonization (the best example here is probably the Algerian FLN movement), while others were motivated by the ideology of nationalism, sometimes also called separatism. The two most widely-known European nationalist movements, who became known to be more than ready to utilize terrorist tactics, were the Irish and Basque nationalists (separatists). More commonly known as the IRA and ETA, they are the most recognized and widely-known European separatist organizations to be labelled terrorist groups. The FLN ultimately managed to regain independence for Algeria, though not solely through terrorism, but also guerrilla tactics and political negotiation. Some might also include the Jewish Zionist fighters in the same league of militants, as they have resorted to terrorist acts in order to gain independence from what they consider foreign occupation, as well as 
Cypriots from the old EOKA movement, who fought the British for the independence of Cyprus. The Algerians, Zionists and Cypriots all succeeded in their efforts, but terrorist tactics played minor roles in their successes, which were largely achieved through military, diplomatic, political and even moral pressure. It's worth noting that some nationalist/separatist movements have ultimately failed to achieve their goal of liberating their people - the best example here is probably the Tamil's LTTE. In Latin America, a whole plethora of 'people liberation' movements emerged in the late 1950s and early '60s, actively supported by Soviet Russia and Maoist China, with the goal of superseding their far-right military regimes with communist-type governments, or at least to subvert the pro-American military authoritarian rule on the continent. Similar far leftist movements could be found in Western Europe, where communist and Maoist ideologies were connected to the counterculture revolution of the late 1960s. As a reaction to it, far-right movements and even political parties based on a neo-Nazi ideology emerged. Radical Marxist, Maoist, neo-communist groups and (in contrast), neofascist and neo-Nazi organizations, all managed to terrorize Western Europe in the 1970s and 1980s, with a third wave of terrorism based on these radical political ideologies. A current, fourth wave, is seemingly connected to the rise of numerous radical and extremist interpretations of the mostly Sunni Islam, based on the Salafi and Wahhabi ideologies, which began its violent existence with the end of the Cold War (i.e. in the 1990s). This wave has lasted until today and seems to yet be flourishing. The most widely-known examples of these religious terrorist groups are Al Qaeda and Islamic State.

\subsubsection{Terrorist organizations, networks and movements}

Table 1. Terrorist Groups - A List of Terrorist Groups by Type: From Pre-Modern to Present-Day, Author: Amy Zalman, Ph.D.

\section{SOCIALIST/COMMUNIST}

Many groups committed to socialist revolution or the establishment of socialist or communist states arose in the last half of the 20th century, and many are now defunct. The most prominent included:

- Baader-Meinhof Group (renamed Red Army Faction, defunct as of 1998) (Germany);

- Popular Front for the Liberation of Palestine (PFLP);

- Red Brigades (Italy);

- Revolutionary Struggle (Greece);

- Shining Path (Peru);

- Weather Underground Organization (United States). 


\section{NATIONAL LIBERATION}

National liberation is historically among the most potent reasons that extremist groups turn to violence to achieve their aims. There are many of these groups, but they have included:

- ETA (Basque);

- Fatah (PLO) (Palestinian);

- Irgun (Zionist);

- IRA (Irish);

- PKK (Kurdish);

- Tamil Tigers (Sri Lankan Tamils);

\section{RELIGIOUS-POLITICAL}

There has been a rise in religiosity globally since the 1970s, and with it a rise in what many analysts call religious terrorism. It would be more accurate to call groups such as Al Qaeda religious-political, or religious-nationalist. We call them religious because they use a religious idiom and shape their 'mandate' in divine terms. Their goals, however, are political: recognition, power, territory, concessions from states, and so on.

Historically, such groups have included:

- Al Qaeda (transnational, Islamist);

- Aum Shinrikyo (renamed Aleph)(Japanese; various influences, including Hindu and Buddhist);

- Klu Klux Klan (U.S.; Christian);

- Abu Sayyaf(Philippines; Islamist);

- Egyptian Islamic Jihad;

- Hamas (Palestinian; Islamist) (Hamas is designated by the U.S. and other governments as a terrorist group, but it is also the elected government of the Palestinian Authority);

- Hezbollah (Hezbollah is designated as a terrorist organization by the U.S. and other governments, but others argue it should be considered a movement, rather than a terrorist group).

Source: https://www.thoughtco.com/terrorist-groups-a-list-of-terroristgroups-by-type-3209111

\subsubsection{How does terrorism end?}

Individually, there are four common ways out of terrorism: through death, imprisonment, entering regular politics, or entering organized crime. Some exterrorists return to a 'normal' life and try to forget their violent past - some even denounce it. This is hard to show with exact numbers because it depends on the specific conflict. Collectively, terrorist organizations can be either violently crushed by the state (LTTE, Baader Meinhof, Red Brigades, November 17), 
surrender (ETA), suspend their activities and join regular political process through peace negotiations (the IRA), or even transform themselves into a political party (Hezbollah) or a quasi-state (PLO, Islamic State). Last, but not least, they sometimes even achieve 'victory' (FLN, Zionist organizations, EOKA), at which point they transform into a legitimate entity, or disband altogether. Some maintain their violent activity for a long time, transforming themselves according to external needs and conditions (e.g. Al Qaeda).

Exercise 1: Find additional information on the structure and activity of selected terrorist group of socialist/communist, national liberation and religious groups. Use Internet sources.

\subsection{The impact of terrorism on the development of EU states}

\subsubsection{Terrorism and modern politics}

Since violence and coercion is visibly present in political relations, both domestically and internationally, it is hard to deny that terrorism is an extension of politics by other means. It seems equally obvious that terrorism is detached from normal, every-day politics, and enters the domain of attracting public attention through ruthless killings, spreading its political message and aiming at submission by extortion. This means that it cannot be accepted as a legitimate form of political interaction, and so is usually fought by state institutions.

\subsubsection{Terrorism and the state}

Political entities use terrorist methods to attack, destroy or transform a state and force its authorities to alter their policies in areas perceived by the terrorists as key. Ultimately, the government of a state is the principal target of terrorist action - in democratic regimes the public has a chance to influence its own government, and so it is sometimes also held responsible by the terrorists ('We kill you because you support the government that is killing us'). In nondemocratic regimes, terrorist entities attempt to influence government indirectly by showing its inability to maintain public order and provoke harsh repression of large sectors of society, which could enable terrorists to gain more social support. Some EU states have extensive experience with various terrorist entities, domestic and international (the United Kingdom, France, Germany, Spain, Italy), and have introduced a wide variety of countermeasures - legal and organizational - and have at their disposal the staff and infrastructure to deal with this problem more or less effectively. For other countries, the threat of terrorism is a relatively new one and they have yet to adjust their functioning and legal system, or develop 
counter-terrorist systems to protect their public. The EU itself actively promotes counter-terrorist co-operation through numerous initiative and policies.

Terrorism is not a new phenomenon in Europe. It poses a threat to our security, to the values of our democratic societies and to the rights and freedoms of European citizens. Between 2009-2013 there were 1,010 failed, foiled or completed attacks carried out in EU member states, in which 38 people died. In addition, several European citizens have been kidnapped or killed by terrorist groups around the world. The phenomenon of fighters from Europe travelling to different locations to fight the jihadists, and the security threat they may pose inside the EU when they return, are also likely to persist in the coming years. Since these threats do not recognise borders, they must be confronted at both a national and international level.

EU counter-terrorism strategy is designed to combat terrorism globally while respecting human rights, and to make Europe safer, allowing its citizens to live in an area of freedom, security and justice. European Union member states are committed to jointly fighting terrorism and providing for the best possible protection of its citizens. To this end, in 2005 the Council adopted the EU counter-terrorism strategy.

The strategy is focused on four main pillars: prevent, protect, pursue and respond. Across these pillars, the strategy recognises the importance of working with third countries and international institutions.

\section{Prevent}

One of the EU's priorities in the field of counter-terrorism is to identify and tackle the factors that contribute to radicalisation, and the processes by which individuals are recruited to commit acts of terror. To this end, the Council has adopted an EU strategy for combating radicalisation and recruitment to terrorism. In light of evolving trends, such as the phenomena of lone actors and foreign fighters, or the growing potential of social media for mobilisation and communication, the Council adopted a revision on this strategy in June 2014. In December 2014, justice and home affairs ministers across the Union adopted a series of guidelines for the revised EU radicalisation and recruitment strategy. These guidelines set out a series of measures to be implemented by the EU and its member states.

\section{Protect}

The second priority of the EU counter-terrorism strategy is the protection of its citizens and infrastructure, and reducing its vulnerability to attack. This includes the protection of external borders, the improvement of transport security, the protection of strategic targets and the reduction of the vulnerability 
of critical infrastructure. In this area, the EU is currently working on legislation regulating the use of passenger name record (PNR) data for law enforcement purposes.

\section{Pursue}

The EU is working to hinder terrorists' capacity to plan and organise, and to bring these terrorists to justice. To achieve these goals, the EU has focused on strengthening national capabilities, improving practical cooperation and information exchange between police and judicial authorities (in particular through Europol and Eurojust), and tackling terrorist financing to deprive terrorists of the means by which they mount their attacks and communicate.

In May 2015, the Council and the European Parliament also adopted new rules to prevent money laundering and terrorist financing.

\section{Respond}

The fourth objective of the EU counter-terrorism strategy is to prepare, in the spirit of solidarity, to manage and minimise the consequences of a terrorist attack. This is done by improving the EU's capability to deal with the aftermath of incidents, coordinate responses, and handle the needs of victims. Priorities in this area include the development of EU crisis co-ordination arrangements, the revision of the civil protection mechanism, the development of risk assessment mechanisms and the sharing of best practices for assisting victims of terrorism.

\section{Priorities in recent years have included:}

1. The definition of the arrangements for the implementation by the EU of the solidarity clause, through a Council decision, adopted in June 2014.

2. A review of the EU emergency and crisis coordination arrangements, replaced by the EU integrated political crisis response arrangements (IPCR), in June 2013.

3. Revision of the EU civil protection legislation, at the end of 2013.

\section{Engagement with international partners}

The security of the European Union is closely linked with developments in other countries, particularly in the neighbouring states, and so the EU counterterrorism strategy needs to be on a global scale.

In the strategic guidelines for justice and home affairs, adopted in June 2014, the European Council called for an effective counter-terrorism policy that integrates internal and external aspects. On 12 February 2015, the EU heads of state and government stressed the importance to the EU of engaging more with third countries on security issues and counter-terrorism. 
In relations between the $\mathbf{E U}$ and third countries, the counter-terrorism agenda is present in many ways, through high level political dialogue, the adoption of cooperation clauses and agreements, and specific assistance and capacitybuilding projects with strategic countries. The EU works on counter-terrorism with countries in the Western Balkans, the Sahel, North Africa, the Middle East, the Horn of Africa and North America, as well as in Asia.

Mutual work with the US is a fundamental component of the EU's strategy. In recent years, agreements have been reached in areas such as the financing of terrorism, transport and borders, mutual legal assistance and extradition. US authorities are working more and more closely with Europol and Eurojust.

Another important part of the external dimension of the fight against terrorism involves working closely with other international and regional organisations to build international consensus and promote international standards for fighting terrorism. The European Union works with international organisations including the UN and the Global Counter Terrorism Forum, and regional organisations such as the Council of Europe, the OSCE, the League of Arab States and the Organisation for Islamic Cooperation.

As part of its work with the UN, and following a number of UN Security Council resolutions, the EU has adopted certain restrictive measures against persons or entities associated with the Al-Qaeda network.

\subsubsection{Possible reactions to terrorist threats}

If terrorism is not incidental and involves prolonged militant activity, a nation is forced to react. It can choose a strategy of combating terrorism, or more rarely, negotiating a political solution with the terrorist entities. Even if they refuse to talk to the terrorists, in some cases, tactical negotiations with terrorists are simply a necessity, e.g. during hostage situations. Though usually a state will declare that they won't negotiate with terrorists, some channels of communication with terrorist organizations are often established, particularly during lengthy conflicts. The primary reaction to a terrorist threat, though, is an attempt to eradicate it, or if this is impossible to limit the influence of the incident through police or even military action. Governments consider terrorism illegal as it is usually based on severe breaches of law and order. Armed attacks, the credible threat of such attacks, killings, abductions and other violent actions are simply crimes, and cannot be tolerated by legal political entities, especially when democratically elected. Amongst other things, terrorists will attempt to usurp a state's monopoly on the use of force and coercion. The authorities tend to deem any non-state form of organized violence illegitimate. But 'combating terrorism' is a demanding and tricky activity, and forces politicians to introduce frequently very extensive changes in domestic legislation to make it easier or more effective. This consumes vast financial, human and organizational resources - one of 
a terrorists' goals is to exhaust both society (by making them live in a condition of constant fear), and the state, which is forced to use vast resources to counter terrorist activity and ultimately change vital public policies.

\subsubsection{The transformation of states by terrorism}

Regardless of how a government reacts, terrorism changes the way it functions. The very nature of the threat - small, clandestine units of devoted militants supported by some section of a society's own population - demands development of very special skills and technical capabilities. This includes extended surveillance of the population, including use of so-called SIGINT and HUMINT techniques, establishment of rapid-reaction special forces as a physical reaction to acts of terrorism, vast investigative skills and powers granted to the police, and establishment of detention camps or special incarceration facilities for captured terrorists. Every country, regardless of its political system, develops police, intelligence and military resources to tackle this threat. To ensure it is acting legally, each state is then forced to introduce new counter-terrorist legislation in order not to be involved in illegitimate actions which would undermine its credibility. To protect its own population and institutions, the state simply must resort to special powers, some of which inevitably affect hard-earned civil liberties.

\subsubsection{Terrorism and society}

Terrorist entities that are alienated from their own society are not usually successful. To be at least partially effective terrorists must be supported by at least some sections of their society, who would be eager to provide safe haven to members of a political group violently opposing the government. The very existence of a prolonged and significant threat by a terrorist group(s) shows the existence of serious divisions within society, which make this kind of conflict possible. These kinds of societal rifts could be based on deep ideological divisions, or ethnic or religious tensions - terrorists are ideologically driven and want to subvert and ultimately change the social and political order within the attacked state. So when there is no social support for this kind of radical, violent action, terrorism promptly fades. But when the threat level increases over the long term, the divisions in society actually widen.

\subsubsection{The politics of counter-terrorism}

The process of countering global terrorist threats becomes a matter of high politics reaching to the far corners of the world, as can be seen post-9/11. Turning counter-terrorism activity into U.S. foreign policy was precisely what the planners behind the 9/11 attacks were trying to achieve. Thanks to the announcement of 
The War on Terror/The Global War on Terrorism) by then-U.S. President George W. Bush, a small group of Sunni extremists, located somewhere in Afghan caves and hardly known prior to that time, became the main enemy of the world's only superpower, dwarfing such threats as Iran, North Korea and even Russia. President Bush's decision to attack not only Afghanistan but also Iraq (a country which had nothing to do with the 9/11 attacks), destabilized the entire Greater Middle East and paved the way for the restoration of the Islamic Caliphate ('Islamic State'), no more than thirteen years after $9 / 11$. This event altered the politics of a superpower, and in this way Al Qaeda manged to hijack the foreign policy of its American opponent. Terrorism is the 'strategy of a mosquito' - a little creature cannot destroy a forest, but by flying into a bear's ear can achieve what it wants by steering the bear's reactions. Al Qaeda, and now Islamic State, have adopted precisely this strategy, transforming the Greater Middle East through the use of the destructive powers of subsequent American administrations. Al Qaeda succeeded in provoking the U.S. to over-react and adapt the wrong counter-terrorist strategy.

Exercise 2. Find information on a selected act of terrorism that happened in an EU state. Present the socio-demographic profile of the perpetrator(s) and the timeline of events leading to the attack, as well as its consequences.

\subsection{Modern terrorism and the 'between war and peace' phenomenon}

\subsubsection{Terrorism as a threat to peace}

The very presence of terrorist entities implies the existence of a political conflict, and this kind of conflict endangers the peaceful development of society. Terrorism is also a grave threat to international peace, both directly - through the direct actions of international and global terrorist organisations, and indirectly - through a states' reaction to terrorism. For example, America's so-called 'War on Terror' resulted in American military interventions in Afghanistan and Iraq and an increased military presence in many African and Asian countries. Terrorism endangers peace through its own violent actions, and by provoking nations to exert violent reactions.

\subsubsection{Is terrorism a form of war?}

No. War is a state of armed conflict engaged in through large-scale military operations. Military forces are distinct from civilian entities, and deliberate and unjustified attacks on civilian targets are usually considered a war crime. Wars are regulated by the international law of armed conflicts and are usually officially 
declared by the government. The mortality rate in war is usually high, affecting entire nations in a physically and mentally destructive way, as aggression alongside the use of modern military technology. A state of war is open and visible and has visibly catastrophic results.

In contrast, terrorism is a clandestine activity, and its perpetrators look like ordinary men and women. However, they do not respect the legal codes of conduct of war, and attacking defenceless targets is their primary - usually sole - tactic. Hence, the physical damage achieved through terrorism is usually limited, and the frequency of its armed attacks usually low. 'Conventional' army, airforce and navy forces are usually not involved in combating terrorism - they may provide a government with the services of their special forces and intelligence units, but the primary resources used by a state to fight terrorists are the police and other emergency and special services.

So although terrorism is not war, neither is it obviously peace - it is instead a social phenomenon located between war and peace. It is a politically motivated violent assault on a state and society aimed at social and political change, carried out in a way that significantly differs from conventional military warfare.

\subsubsection{Terrorism and the local, regional and global order}

Depending on the political agenda of the terrorist entity, the results of their activity can be visible at the local, regional and global levels. The IRA and ETA affected Britain and Spain directly, but did not really have a profile elsewhere, even if their terrorists operated in other countries. The Israeli-Palestinian conflict, a continuing series of terrorist attacks and counter-terrorist responses, ultimately managed to transform the entire Middle East and frequently took place beyond its borders (largely in Europe). Today, the influence of Al Qaeda and the Islamic State is truly global, affecting almost all continents.

\subsubsection{Terrorism as an act of communication}

Terrorism is also presented as an act of political communication - of conveying a meaningful message from one individual or group to another. The intended violence with it amplifies this political message and the seriousness of the attitude of the sender. Hence, modern and post-modern mass media, as well as social media, all play a vital and necessary role in spreading this message - they are an essential part of the 'terrorist process'. Newspapers, radio, television and now social media have always been extensively used to present the political justification of acts of violence, the demands of terrorists, their views, opinions and attitudes towards the government and public opinion. People willing and able to kill their fellow citizens for political reasons have never been neglected or ignored - on the contrary, even the most obviously unreasonable or senseless 
terrorist communiques were carefully listened to and meticulously analysed. Killing innocents to attract public attention has always proved to be an effective tactic. Perceiving terrorism as propaganda by deed has was as much a thing in the early days of anarchism and newspapers, over a century ago, as it is today, in the era of jihadi fighters and Twitter.

\subsubsection{Civilizations and terrorism}

In the case of a jihad, terrorism is the preferred tactic everywhere that the jihadists are unable to use other forms of violence, such as guerrilla or conventional warfare, or even genocide. The jihadists perceive their fight as a divine obligation, an act of defence of their sacrosanct Islamic umma (community) and civilization. Their aim is to enforce submission to the one and only 'true' religion. In this way, their aims are non-negotiable and impossible to meet through any kind of partial concession. Total and ultimate surrender is simply needed to meet the jihadists' demands, and this makes conventional politics obsolete. Warfare becomes the only available option in response to this type of violence.

\subsubsection{Religious terrorism}

Absolute religious goals change the nature of terrorism - it is no longer politics by other means, but rather a method of conquest. In this way, religious terrorism is a punishment for sins, a road to individual salvation, an act of sacrifice in the name of an imagined community, and an attempt to achieve a pure and pious form of society. The supernatural character of jihadi Salafi groups aiming for religious piety and its expansion radically change the very nature of their terrorist threats. It literally precludes the possibility of proposing, then entering, a peace process, and reaching a political solution through negotiations with the terrorists' political wing(s), as happened in the Irish conflict.

Exercise 3. Find information on a terrorist attack perpetrated by Al Qaeda operatives since $9 / 11 / 2001$. Present a timeline of events leading to this attack and its consequences.

\subsection{Terrorist use of CBRN agents}

\subsubsection{Terrorist acts using CBRN weapons}

The following table summarizes known historical instances of the use of chemical, radiological and biological weapons, in reverse chronological order. The listing is limited to events since 1900 (while there were some earlier instances 
of chemical/biological warfare, these instances were generally of very limited effectiveness). Note that some incidents are disputed, and casualty figures in some cases are very uncertain. Sources are provided following the table.

Table 2. Historical summary of attacks using chemical, radiological and biological weapons, compiled by Wm. Robert Johnston (last updated 30 November, 2016)

\begin{tabular}{|c|c|c|c|c|c|c|}
\hline Date & Location & Attacker & Agent & $\begin{array}{c}\text { Affected } \\
\text { pop }\end{array}$ & $\begin{array}{c}\text { Casual- } \\
\text { ties }\end{array}$ & Description \\
\hline $\begin{array}{l}21-27 \\
\text { Oct } \\
2016\end{array}$ & $\begin{array}{l}\text { near Mosul, } \\
\text { Iraq }\end{array}$ & $\begin{array}{l}\text { Islamic } \\
\text { State } \\
\text { militants }\end{array}$ & sulfur & $\begin{array}{l}\text { civilians, } \\
\text { soldiers }\end{array}$ & $\begin{array}{l}\text { 2 killed, } \\
1,500 \\
\text { injured }\end{array}$ & $\begin{array}{l}\text { sulfur mine set } \\
\text { on fire, produc- } \\
\text { ing widespread } \\
\text { sulfur dioxide } \\
\text { plumes }\end{array}$ \\
\hline $\begin{array}{l}8 \mathrm{Mar} \\
2016\end{array}$ & $\begin{array}{l}\text { Taza, Kirkuk, } \\
\text { Iraq }\end{array}$ & $\begin{array}{l}\text { Islamic } \\
\text { State }\end{array}$ & $\begin{array}{l}\text { blis- } \\
\text { tering } \\
\text { agent }\end{array}$ & civilians & $\begin{array}{l}1 \text { killed, } \\
600 \\
\text { injured }\end{array}$ & $\begin{array}{l}\text { attack on } \\
\text { a town; fatality } \\
\text { was 3-year-old } \\
\text { child }\end{array}$ \\
\hline $\begin{array}{l}23 \mathrm{Jan} \\
2015\end{array}$ & $\begin{array}{l}\text { between Mosul, } \\
\text { Iraq, and Syrian } \\
\text { border }\end{array}$ & $\begin{array}{l}\text { Islamic } \\
\text { State } \\
\text { militants }\end{array}$ & $\begin{array}{l}\text { chlo- } \\
\text { rine }\end{array}$ & $\begin{array}{l}\text { Kurdish } \\
\text { soldiers }\end{array}$ & $\begin{array}{l}\sim 30 \\
\text { injured }\end{array}$ & $\begin{array}{l}\text { truck bomb } \\
\text { with chlo- } \\
\text { rine-filled } \\
\text { tanks used } \\
\text { against troops } \\
\end{array}$ \\
\hline $\begin{array}{l}\text { Sep-Oct } \\
2014\end{array}$ & $\begin{array}{l}\text { Duluiya and } \\
\text { Balad, Iraq }\end{array}$ & $\begin{array}{l}\text { Islamic } \\
\text { State } \\
\text { militants }\end{array}$ & \begin{tabular}{|l|} 
chlo- \\
rine, \\
possibly \\
mustard \\
gas \\
\end{tabular} & $\begin{array}{l}\text { Iraqi and } \\
\text { Shiite } \\
\text { soldiers }\end{array}$ & $\begin{array}{l}40 \\
\text { injured }\end{array}$ & $\begin{array}{l}\text { bombs with } \\
\text { chlorine-filled } \\
\text { cylinders used } \\
\text { against defend- } \\
\text { ing troops } \\
\end{array}$ \\
\hline $\begin{array}{l}\text { Apr } \\
2012- \\
\text { Jun } 2013\end{array}$ & $\begin{array}{l}\text { Afghani- } \\
\text { stan--Takhar } \\
\text { province (9), } \\
\text { Sar-e-Pul prov- } \\
\text { ince (4), others }\end{array}$ & $\begin{array}{l}\text { Islamist } \\
\text { terrorists }\end{array}$ & $\begin{array}{l}\text { pesti- } \\
\text { cides? }\end{array}$ & $\begin{array}{l}\text { school- } \\
\text { children }\end{array}$ & $\begin{array}{l}1,952 \\
\text { injured } \\
\text { (in- } \\
\text { cluding } \\
1,924 \\
\text { chil- } \\
\text { dren) }\end{array}$ & $\begin{array}{l}23 \text { poison } \\
\text { attacks on girls' } \\
\text { schools, some } \\
\text { cases of water } \\
\text { poisoning }\end{array}$ \\
\hline $\begin{array}{l}\text { Mar } \\
2012 \\
-A p r \\
2013\end{array}$ & Afghanistan & $\begin{array}{l}\text { Islamist } \\
\text { terrorists }\end{array}$ & $\begin{array}{l}\text { rat poi- } \\
\text { son? }\end{array}$ & $\begin{array}{l}\text { police, } \\
\text { other } \\
\text { civilians }\end{array}$ & $\begin{array}{l}\mathbf{5 3} \\
\text { killed, } \\
40 \\
\text { injured }\end{array}$ & $\begin{array}{l}9 \text { attacks in- } \\
\text { volving poison- } \\
\text { ing of food at } \\
\text { police stations } \\
\text { academies }\end{array}$ \\
\hline
\end{tabular}


Table 2. cont.

\begin{tabular}{|c|c|c|c|c|c|c|}
\hline Date & Location & Attacker & Agent & $\begin{array}{c}\text { Affected } \\
\text { pop }\end{array}$ & $\begin{array}{c}\text { Casual- } \\
\text { ties }\end{array}$ & Description \\
\hline $\begin{array}{l}\text { Apr- } \\
\text { Aug } \\
2010\end{array}$ & $\begin{array}{l}\text { Afghani- } \\
\text { stan--Kabul } \\
\text { (6), Kunduz } \\
\text { (4), others }\end{array}$ & $\begin{array}{l}\text { Islamist } \\
\text { terrorists }\end{array}$ & $\begin{array}{l}\text { pesti- } \\
\text { cides? }\end{array}$ & $\begin{array}{l}\text { school- } \\
\text { children }\end{array}$ & $\begin{array}{l}672 \\
\text { injured } \\
\text { (includ- } \\
\text { ing 636 } \\
\text { chil- } \\
\text { dren) } \\
\end{array}$ & $\begin{array}{l}20 \text { gas at- } \\
\text { tacks on girls' } \\
\text { schools }\end{array}$ \\
\hline $\begin{array}{l}11 \text { Mar } \\
2007\end{array}$ & Iraq & $\begin{array}{l}\text { Islamist } \\
\text { terrorists }\end{array}$ & $\begin{array}{l}\text { mustard } \\
\text { gas }\end{array}$ & $\begin{array}{l}\text { U.S. sol- } \\
\text { diers }\end{array}$ & 2 injured & $\begin{array}{l}\text { failed im- } \\
\text { proved explo- } \\
\text { sive device } \\
\text { using chemical } \\
\text { weapon artil- } \\
\text { lery shells }\end{array}$ \\
\hline $\begin{array}{l}\text { Oct } \\
2006- \\
\text { Jun } 2007\end{array}$ & $\begin{array}{l}\text { Iraq cities - } \\
\text { Ramadi (6), } \\
\text { Baghdad (3), } \\
\text { Falluja (3), } \\
\text { others }\end{array}$ & $\begin{array}{l}\text { Islamist } \\
\text { terrorists }\end{array}$ & $\begin{array}{l}\text { chlo- } \\
\text { rine }\end{array}$ & $\begin{array}{l}\text { civilian } \\
\text { targets }\end{array}$ & $\begin{array}{l}115 \\
\text { killed*, }^{*} \\
854 \\
\text { injured } \\
\text { (includ- } \\
\text { ing } 85 \\
\text { chil- } \\
\text { dren) }\end{array}$ & $\begin{array}{l}15 \text { car/truck } \\
\text { bombings with } \\
\text { chlorine tanks } \\
\text { used; most } \\
\text { fatalities were } \\
\text { from the ex- } \\
\text { plosions, most } \\
\text { injuries from } \\
\text { the chemical } \\
\text { releases }\end{array}$ \\
\hline $\begin{array}{l}8 \text { Oct } \\
2006\end{array}$ & $\begin{array}{l}\text { Numaniyah, } \\
\text { Iraq }\end{array}$ & $\begin{array}{l}\text { Islamist } \\
\text { terrorists }\end{array}$ & poison & $\begin{array}{l}\text { police- } \\
\text { men }\end{array}$ & $\begin{array}{l}7 \text { killed, } \\
700 \\
\text { injured }\end{array}$ & $\begin{array}{l}\text { poisoning of } \\
\text { meals on police } \\
\text { base; un-con- } \\
\text { firmed }\end{array}$ \\
\hline $\begin{array}{l}25 \text { Sep } \\
2006\end{array}$ & Baghdad, Iraq & $\begin{array}{l}\text { Islamist } \\
\text { terrorists }\end{array}$ & $\begin{array}{l}\text { mustard } \\
\text { gas }\end{array}$ & $\begin{array}{l}\text { U.S. sol- } \\
\text { diers }\end{array}$ & 2 injured & $\begin{array}{l}\text { improved ex- } \\
\text { plosive device } \\
\text { using chemical } \\
\text { weapon artil- } \\
\text { lery shells }\end{array}$ \\
\hline
\end{tabular}




\begin{tabular}{|c|c|c|c|c|c|c|}
\hline Date & Location & Attacker & Agent & $\begin{array}{l}\text { Affected } \\
\text { pop }\end{array}$ & $\begin{array}{c}\text { Casual- } \\
\text { ties }\end{array}$ & Description \\
\hline $\begin{array}{l}15 \text { May } \\
2004\end{array}$ & Baghdad, Iraq & $\begin{array}{l}\text { Islamist } \\
\text { terrorists }\end{array}$ & $\begin{array}{l}\text { sarin } \\
\text { nerve } \\
\text { gas }\end{array}$ & $\begin{array}{l}\text { U.S. sol- } \\
\text { diers }\end{array}$ & 2 injured & $\begin{array}{l}\text { failed impro- } \\
\text { vised explo- } \\
\text { sive device } \\
\text { using chem- } \\
\text { ical weapon } \\
\text { artillery shell } \\
\text { near Baghdad } \\
\text { airport }\end{array}$ \\
\hline $\begin{array}{l}\text { 24 Jun - } \\
\text { Jul } 2003\end{array}$ & $\begin{array}{l}\text { near Mosul, } \\
\text { Iraq }\end{array}$ & $\begin{array}{l}\text { Islamist } \\
\text { terrorists }\end{array}$ & sulfur & $\begin{array}{l}\text { civilians, } \\
\text { soldiers }\end{array}$ & ? injured & $\begin{array}{l}\text { sulfur stock- } \\
\text { piles at mine } \\
\text { set on fire, } \\
\text { producing } \\
\text { widespread } \\
\text { sulfur dioxide } \\
\text { plumes; at least } \\
41 \text { U.S. soldiers } \\
\text { injured }\end{array}$ \\
\hline $\begin{array}{l}18 \text { Sep } \\
-9 \text { Oct } \\
2001\end{array}$ & $\begin{array}{l}\text { United States } \\
\text {-Washington, } \\
\text { DC, New York } \\
\text { City, NY, others }\end{array}$ & $\begin{array}{l}\text { Bruce } \\
\text { Ivins? }\end{array}$ & anthrax & $\begin{array}{l}\text { govern- } \\
\text { ment and } \\
\text { civilian } \\
\text { media } \\
\text { individu- } \\
\text { als; postal } \\
\text { employ- } \\
\text { ees and } \\
\text { customer }\end{array}$ & $\begin{array}{l}\text { 5 killed, } \\
17 \\
\text { injured }\end{array}$ & $\begin{array}{l}\text { anthrax-laced } \\
\text { letters mailed } \\
\text { to federal } \\
\text { officials in } \\
\text { Washington } \\
\text { DC and new } \\
\text { media offices } \\
\text { in multiple lo- } \\
\text { cations; many } \\
\text { casualties } \\
\text { among postal } \\
\text { workers }\end{array}$ \\
\hline $\begin{array}{l}20 \text { Mar } \\
1995\end{array}$ & Tokyo & $\begin{array}{l}\text { Aum } \\
\text { Shinri- } \\
\text { kyo cult }\end{array}$ & $\begin{array}{l}\text { sarin } \\
\text { nerve } \\
\text { gas }\end{array}$ & $\begin{array}{l}\text { Tokyo } \\
\text { subway }\end{array}$ & $\begin{array}{l}12 \\
\text { killed, } \\
5,511 \\
\text { injured }\end{array}$ & $\begin{array}{l}\text { nerve gas } \\
\text { releases in } \\
\text { subway; many } \\
\text { permanent } \\
\text { injuries }\end{array}$ \\
\hline $\begin{array}{l}28 \text { Jun } \\
1994\end{array}$ & $\begin{array}{l}\text { Matsumoto, } \\
\text { Japan }\end{array}$ & $\begin{array}{l}\text { Aum } \\
\text { Shinri- } \\
\text { kyo cult }\end{array}$ & $\begin{array}{l}\text { sarin } \\
\text { nerve } \\
\text { gas }\end{array}$ & civilians & $\begin{array}{l}7 \text { killed, } \\
270 \\
\text { injured }\end{array}$ & $\begin{array}{l}\text { overnight } \\
\text { release of nerve } \\
\text { gas in city }\end{array}$ \\
\hline
\end{tabular}


Table 2. cont.

\begin{tabular}{|c|c|c|c|c|c|c|}
\hline Date & Location & Attacker & Agent & $\begin{array}{c}\text { Affected } \\
\text { pop }\end{array}$ & $\begin{array}{c}\text { Casual- } \\
\text { ties }\end{array}$ & Description \\
\hline $\begin{array}{l}21 \mathrm{Jan} \\
1994\end{array}$ & $\begin{array}{l}\text { Ormancik, } \\
\text { Turkey }\end{array}$ & terrorists & $\begin{array}{l}\text { chem- } \\
\text { ical } \\
\text { agent }\end{array}$ & civilians & $\begin{array}{l}16 \\
\text { killed }\end{array}$ & $\begin{array}{l}\text { attack on } \\
\text { village using } \\
\text { chemical gre- } \\
\text { nades }\end{array}$ \\
\hline $\begin{array}{l}6 \text { Sep } \\
1987\end{array}$ & $\begin{array}{l}\text { Zamboanga } \\
\text { City, Philip- } \\
\text { pines }\end{array}$ & terrorists & poison & $\begin{array}{l}\text { police- } \\
\text { men }\end{array}$ & $\begin{array}{l}19 \\
\text { killed, } \\
140 \\
\text { injured }\end{array}$ & $\begin{array}{l}\text { water poi- } \\
\text { soning with } \\
\text { pesticide at } \\
\text { constabulary }\end{array}$ \\
\hline $\begin{array}{l}9-19 \\
\text { Sep } \\
1984\end{array}$ & $\begin{array}{l}\text { The Dalles, } \\
\text { Oregon, United } \\
\text { States }\end{array}$ & $\begin{array}{l}\text { Bhadwan } \\
\text { Shree } \\
\text { Rajneesh } \\
\text { cult }\end{array}$ & $\begin{array}{l}\text { salmo- } \\
\text { nella }\end{array}$ & $\begin{array}{l}\text { civilian } \\
\text { restau- } \\
\text { rants }\end{array}$ & $\begin{array}{l}751 \\
\text { injured }\end{array}$ & $\begin{array}{l}\text { food poison- } \\
\text { ing in several } \\
\text { restaurants; } \\
\text { was exper- } \\
\text { iment in } \\
\text { preparation to } \\
\text { interfere with } \\
\text { upcoming } \\
\text { election }\end{array}$ \\
\hline $\begin{array}{l}14 \text { Apr } \\
1946\end{array}$ & $\begin{array}{l}\text { Camp Stalag } \\
\text { 13, Nuremberg, } \\
\text { Germany }\end{array}$ & $\begin{array}{l}\text { Jewish } \\
\text { terrorists }\end{array}$ & cyanide & $\begin{array}{l}\text { SS prison- } \\
\text { ers }\end{array}$ & $\begin{array}{l}2,283 \\
\text { injured }\end{array}$ & $\begin{array}{l}\text { poisoning of } \\
\text { bread for Nazi } \\
\text { prisoners }\end{array}$ \\
\hline
\end{tabular}

\subsubsection{The science of terrorism}

In order to increase the deadly effects of their actions, terrorists are constantly seeking innovative ways of killing people, including with weapons of mass destruction. As chemical agents are the easiest to produce, develop and utilise, they tend to concentrate on this aspect of CBRN options. However, it is alleged that Al Qaeda operatives have managed to experiment not only with chemical, but also biological agents, and were actively seeking the means of developing radiological devices.

\section{Nuclear terrorism - towards a real Armageddon?}

Assembling a fully working nuclear device is out of most terrorists' reach. As long as they are not given a device or are unable to steal it, use of nuclear devices in a terrorist attack is highly unlikely. More likely is an attack with the use of a radiological bomb - a device often called a 'dirty bomb'. 
A 'dirty bomb' is a type of radiological dispersal device (RDD) that combines conventional explosives, such as dynamite, with radioactive material. The terms dirty bomb and RDD are often used interchangeably in the media. But most RDDs do not release enough radiation to kill people or cause severe illness - the conventional explosive itself is more harmful to individuals than the radioactive material. However, depending on the situation, an RDD explosion can create tremendous fear and panic, contaminate property, and require potentially costly clean-up. Making prompt, accurate information available to the public can prevent the panic sought by terrorists.

A dirty bomb is in no way similar to a nuclear weapon, or nuclear bomb. A nuclear bomb creates an explosion that is millions of times more powerful than that of a dirty bomb. The cloud of radiation from a nuclear bomb could spread tens to hundreds of square miles, whereas a dirty bomb's radiation could be dispersed within a few blocks or miles of the explosion. A dirty bomb is not a Weapon of Mass Destruction, but a Weapon of Mass Disruption, with which contamination and anxiety are the terrorists' major objectives. RDDs appeal to terrorists because they require limited technical knowledge to build and deploy compared to a nuclear device. Also, the radioactive materials in RDDs are widely used in medicine, agriculture, industry and research, and are easier to obtain than weapons grade uranium or plutonium.

\section{The impact of Dirty Bombs}

The extent of local contamination depends on a number of factors, including the size of the explosive, the amount and type of radioactive material used, the means of dispersal, and the weather conditions. Those closest to the $\mathrm{RDD}$ would be the most likely to sustain injuries from the actual explosion. As radioactive material spreads, it becomes less concentrated and less harmful. Prompt detection of the type of radioactive material used would greatly assist local authorities in advising the community on protective measures, such as sheltering in place, or evacuating the immediate area. Radiation can be readily detected with equipment already carried by many emergency responders. Still, subsequent decontamination of the affected area can involve considerable time and expense. The health effects of radiation tend to be directly proportional to the dose of radiation received - the higher the dose, the higher the risk of injury.

\section{Sources of Radioactive Material}

Radioactive material is routinely used in hospitals, research facilities, industrial activities and on construction sites. These radioactive materials are used for purposes such as diagnosing and treating illnesses, sterilizing equipment and inspecting welding seams. In the United States, the Nuclear Regulatory 
Commission, together with 37 Agreement States, which also regulate radioactive material, administer more than 22,000 licenses for such materials. The vast majority of these materials are not viable for use in RDDs.

\section{Control of Radioactive Material}

In America, the NRC and state regulations require owners licensed to use or store radioactive material to secure it from theft and unauthorized access. These measures have been greatly strengthened since the attacks of September 11, 2001. Licensees must promptly report lost or stolen risk-significant radioactive material. 'Risk-significant' refers to radioactive sources that could pose a significant risk to individuals, society and the environment if not properly used, protected, or secured. Local authorities also assist in making a determined effort to find and retrieve such sources. Most reports of lost or stolen material involve small or short-lived radioactive sources that are not viable for use in RDDs.

Past experience suggests that there has not been a pattern behind the collection of such sources for the purpose of assembling an $\mathrm{RDD}$. It is important to note that the radioactivity of the combined total of all unrecovered sources over the past 8 years (when corrected for radioactive decay), would not reach the threshold for one highrisk radioactive source. Unfortunately, the same cannot be said world-wide.

The U.S. Government is working to strengthen security for high-risk radioactive sources both at home and abroad. The NRC and its 37 Agreement States - states who have been given authority to regulate nuclear materials within their borders - have worked together to create a strong and effective regulatory safety and security framework that includes licensing, inspection, and enforcement.

The NRC also works with other Federal agencies, the International Atomic Energy Agency, and licensees to protect radioactive material from theft and unauthorized access. The agency has made improvements and upgrades to the joint NRC-DOE (Department of Energy) database that tracks the location and movement of certain forms and quantities of special nuclear material. In addition, in early 2009, NRC deployed its new National Source Tracking System, designed to track high-risk sources in the United States on a continuous basis.

\section{Risk of Cancer}

Just because a person is near a radioactive source for a short time or gets a small amount of radioactive dust on themselves does not mean that they will get cancer. Any additional risk will likely be extremely small. Doctors specializing in radiation health effects will be able to assess the risks and suggest what medical treatment, if any, is needed once the radioactive source and exposure levels have been determined.

There are some medical treatments available that help cleanse the body of certain radioactive materials following a radiological accident. Prussian blue 
has been proven effective for ingestion of cesium-137 (a radioactive isotope). In addition, potassium iodide (KI) can be used to protect against thyroid cancer caused by iodine-131 (radioactive iodine). However, KI, which is available over the counter, offers no protection to other parts of the body or against other radioactive isotopes. Ultimately, medical professionals are best qualified to determine how to best treat symptoms.

Exercise 4. Find information on a terrorist attack that used CBRN weapons and present a description of the consequences.

\subsection{Terrorist crimes in Polish and international criminal codes}

\subsubsection{Terrorism - is one man's terrorist another man's freedom fighter?}

This subjectively false dilemma is supposedly responsible for the lack of coherent international legislation on terrorist action that is accepted by all states. As discussed previously, terrorism is a method of warfare, and a terrorist's 'cause' is irrelevant here. Hence, terrorists are considered to be all those who are involved in attacking defenceless members of their own or another society, regardless of the ultimate purpose of their fight, or cause. At the same time, the term 'terror state' could be applied to any state terrorizing its own or other populations for political reasons. Nevertheless, this view is not commonly held, and so international law was, is and will be, full of differing legal opinions that lack a universal vision, unifying EU legislation in terms of acts of terrorism.

\subsubsection{Terrorism and guerrilla warfare}

There is a fundamental difference between guerrilla warfare and terrorism. The former implies an armed assault delivered by small paramilitary units against military targets that are actively involved in (or needed to conduct) military operations. Terrorism implies an assault on non-combatant, defenceless targets. Even soldiers and policemen can be considered non-combatants when they are off duty, or not taking part in combat operations. When guerilleros choose to attack civilians, they abandon the path of an irregular (yet legally recognised) type of warfare, and enter the path of terrorism.

\subsubsection{Terrorism and the rules of war}

Put simply, war implies attacks on legitimate military targets. Terrorism implies unlawful attacks on non-combatants. 
Table 3. The 10 Rules of War

\begin{tabular}{|c|l|}
\hline \multicolumn{2}{|c|}{ The rules of war, also known as international humanitarian law } \\
\hline 1. & Protect those who are not fighting, such as civilians, medical personnel and aid workers. \\
\hline 2. & Protect those who are no longer able to fight, such as injured soldiers or prisoners. \\
\hline 3. & Prohibit the targeting of civilians. Doing so is a war crime. \\
\hline 4. & $\begin{array}{l}\text { Recognize the right of civilians to be protected from the dangers of war and } \\
\text { receive the help they need. Every possible care must be taken to avoid harming } \\
\text { them or their houses, or destroying their means of survival, such as water sources, } \\
\text { crops, livestock, etc. }\end{array}$ \\
\hline 5. & $\begin{array}{l}\text { Mandate that the sick and wounded have a right to be cared for, regardless of } \\
\text { whose side they are on. }\end{array}$ \\
\hline 6. & $\begin{array}{l}\text { Specify that medical workers, medical vehicles and hospitals dedicated to huma- } \\
\text { nitarian work cannot be attacked. }\end{array}$ \\
\hline 7. & Prohibit torture and degrading treatment of prisoners. \\
\hline 8. & $\begin{array}{l}\text { Specify that detainees must receive food and water and be allowed to communi- } \\
\text { cate with their loved ones. }\end{array}$ \\
\hline 9. & Limit the weapons and tactics that can be used in war, to avoid unnecessary suffering. \\
\hline 10. & $\begin{array}{l}\text { Explicitly forbid rape and other forms of sexual violence in the context of armed } \\
\text { conflict. }\end{array}$ \\
\hline
\end{tabular}

Source: https://www.icrc.org/en/document/10-things-rules-of-war-Geneva-Conventions

\subsubsection{The legal approach to terrorism}

Every state involved in counter-terrorist activities has developed its own legislation to solve the legal questions in combating and preventing terrorism.

\subsubsection{Terrorism in Polish and international legislation}

Since the $1^{\text {st }}$ of May 2004, the Polish penal code has adapted the term "terrorist related crime", in $\$ 20$ of art. 115 . On the $2^{\text {nd }}$ of July 2016 , Poland brought into force its very first Counter-terrorist Act, which provides Polish state institutions with special powers to investigate, prevent and react to terrorist threats. Amendments to Polish Criminal Law have been made to punish the financing of terrorism, participation in terrorist training, the spreading of terrorist propaganda, the provision of assistance to terrorist activities and even refraining from informing the police about possible terrorist attacks. In contrast, international law lacks a unified convention on terrorism and is based on bilateral and multilateral agreements and conventions, as well as several sectoral U.N. conventions dealing with a variety of different terrorist-related activities. 
Table 4. International Conventions on Terrorism - Related Crimes

1. Convention on Offences and Certain Other Acts Committed On Board Aircraft (1963) http://treaties.un.org/doc/db/Terrorism/Conv1-english.pdf

2. Convention for the Suppression of Unlawful Seizure of Aircraft (1970) http:// treaties.un.org/doc/db/Terrorism/Conv2-english.pdf Protocol Supplementary to the Convention for the Suppression of Unlawful Seizure of Aircraft (2010) http://legacy.icao.int/DCAS2010/restr/docs/beijing_protocol_multi.pdf

3. Convention for the Suppression of Unlawful Acts against the Safety of Civil Aviation (1971) http://treaties.un.org/doc/db/Terrorism/Conv3-english.pdf

4. Convention on the Prevention and Punishment of Crimes Against Internationally Protected Persons (1973) http://treaties.un.org/doc/db/ Terrorism/english-18-7.pdf

5. International Convention against the Taking of Hostages (1979) http:// treaties.un.org/doc/db/Terrorism/english-18-5.pdf

6. Convention on the Physical Protection of Nuclear Material (1980) http:// treaties.un.org/doc/db/Terrorism/english-18-5.pdf

7. Protocol for the Suppression of Unlawful Acts of Violence at Airports Serving International Civil Aviation, supplementary to the Convention for the Suppression of Unlawful Acts against the Safety of Civil Aviation (1988) http://treaties.un.org/doc/db/Terrorism/Conv7-english.pdf

8. Convention for the Suppression of Unlawful Acts against the Safety of Maritime Navigation (1988) http://treaties.un.org/doc/db/Terrorism/Conv8-english. pdf Protocol to the Convention for the Suppression of Unlawful Acts against the Safety of Maritime Navigation (2005) https://www.unodc.org/tldb/ en/2005_Protocol2Convention_Maritime\%20Navigation.html

9. Protocol for the Suppression of Unlawful Acts against the Safety of Fixed Platforms Located on the Continental Shelf (1988) http://treaties.un.org/ $\mathrm{doc} / \mathrm{db} /$ Terrorism/Conv9-english.pdf Protocol to the Protocol for the Suppression of Unlawful Acts against the Safety of Fixed Platforms Located on the Continental Shelf http://cil.nus.edu.sg/2005/2005-protocol-to-the-1988protocol-for-the-suppression-of-unlawful-acts-against-the-safety-of-fixedplatforms-located-on-the-continental-shelf/

10. Convention on the Marking of Plastic Explosives for the Purpose of Detection (1991) http://treaties.un.org/doc/db/Terrorism/Conv10-english.pdf

11. International Convention for the Suppression of Terrorist Bombing (1997) http://treaties.un.org/doc/db/Terrorism/english-18-9.pdf

12. International Convention for the Suppression of the Financing of Terrorism (1999) http://treaties.un.org/doc/db/Terrorism/english-18-11.pdf

13. International Convention for the Suppression of Acts of Nuclear Terrosism Nuclear Terrorism Convention (2005) http://treaties.un.org/doc/db/ Terrorism/english-18-15.pdf

14. Convention on the Suppression of Unlawful Acts Relating to International Civil Aviation (2010) 
Exercise 5: Find the text of a selected legal convention or act regulating the fight against terrorism. Present the most important issues.

\section{References}

Bar S., Warrant for Terror. The Fatwas of Radical Islam and the Duty to Jihad, Rowman \& Littlefield Publishers, Lanham 2006.

Berger J.M., Stern J., ISIS: The State of Terror, William Collins, London 2015.

Bostom A. (ed.), The Legacy of Jihad. Islamic Holy War and the Fate of Non-Muslims, Prometheus Books Amherst, New York 2006.

Byman D., Deadly Connections: States That Sponsor Terrorism, Cambridge University Press, Cambridge 2005.

Cockburn P., The Rise of Islamic State: ISIS and the New Sunni Revolution, Verso, London 2015.

Coll S., Ghost Wars: The Secret History of the CIA, Afghanistan and Bin Laden, from the Soviet Invasion to September 10, 2001, Penguin, London 2005.

Cronin A.K., How Terrorism Ends. Understanding the Decline and Demise of Terrorist Campaigns, Princeton University Press, New Jersey 2011.

Ganor B., Defining Terrorism. Is One Man's Terrorist Another Man's Freedom Fighter?, http://www.ict.org.il/

Habeck M., Knowing the Enemy. Jihadist Ideology and the War on Terror, Yale University Press, New Haven 2006.

Hammes T.X., The Sling and the Stone. On War in the $21^{\text {st }}$ Century, Zenith Press, St. Paul MN 2004.

Hassan H., Weiss M., ISIS: Inside the Army of Terror, Regan Arts, Washington D.C. 2015.

Immenkamp B., ISIL/Da'esh and non-conventional weapons of terror, European Parliamentary Research Service 2016.

Kilcullen D., The Accidental Guerrilla: Fighting Small Wars in the Midst of a Big One, Oxford University Press, New York 2009.

Laqueur W., Voices of Terror, Reed Press, New York 2004.

Lia B., Architect of Global Jihad: The Life of Al Qaeda Strategist Abu Mus'ab Al-Suri, Columbia University Press, New York 2008.

Nesser P., Islamist Terrorism in Europe. A History, Hurst, London 2016.

Pantucci R., "We love death as you love life". Britain's suburban terrorists, Hurst \& Co, London 2015.

Rappaport D.C., The Four Waves of Modern Terrorism in Terrorism: Critical Concepts in Political Science, vol. 4. The Fourth or Reigious Wave, Routledge, Abingdon 2006.

Sageman M., Leaderless Jihad. Terror Networks in the Twenty - First Century, University of Pennsylvania Press, Philadelphia 2008.

Townshend C., Terrorism: A Very Short Introduction, Oxford University Press, Oxford 2011. Vidino L., Al Qaeda in Europe. The New Battleground of International Jihad, Prometheus Books, Amherst, New York 2005.

Wright L., The Looming Tower: Al-Qaeda and the Road to 9/11, Alfred A. Knopf, New York 2006. 